\title{
The Effect of Renal Perfusion Pressure on the Net Transport of Sodium Out of Distal Tubular Urine As Studied with the Stop-Flow Technique *
}

\author{
Louis Tobian, Karen Coffee, Dorothy Ferreira, and Judith Meuli \\ (From the Department of Internal Medicine, University of Minnesota Hospital and School of \\ Medicine, Minneapolis, Minn.)
}

The rate of sodium filtration through the glomeruli, as well as the concentration of aldosterone in body fluids, undoubtedly influences the renal excretion of sodium. However, that sodium excretion can change even though the filtration rate for sodium remains constant (1-5) has been amply demonstrated. The rate of glomerular filtration can also change considerably without any concomitant changes in sodium excretion $(3,6)$. Moreover, patients with severe Addison's disease, maintained on cortisone, are unable to increase their output of aldosterone or other corticosteroids but, without any obvious change in glomerular filtration, are quite capable of quickly retaining sodium when blood is trapped in the legs or when they stand quietly (2). Observations such as these strongly suggest the presence of additional mechanisms governing the renal excretion of sodium.

In searching for such a mechanism, we were struck with the possible interrelationship of three concepts: first, that most states of sodium retention are associated with underdistention of the arterial tree $(7,8)$; second, that increases in the pressure of blood perfusing a kidney lead to a sodium diuresis (9), whereas decreases in perfusion pressure lead to sodium retention $(3,4)$; and third, that the granular juxtaglomerular cells lying in the medial layer of the afferent glomerular arteriole seem to change their rate of secretion with different degrees of stretch (10), thus appearing to monitor the degree of distention of the

\footnotetext{
* Submitted for publication March 16, 1963 ; accepted September 26, 1963.

Supported by grants from the American Heart Association, from the National Heart Institute, U. S. Public Health Service (H-2008), and from the Cargill Fund. The work was presented at the meeting of the American Society for Clinical Investigation, April 30,
} 1962. arterial tree. Through such an interrelationship, one could reason that the underdistention of the renal arterial bed, which is associated with states of sodium retention, stimulates the juxtaglomerular cells to hypersecrete.

This contention is upheld in four separate situations involving sodium retention: aminonucleoside nephrosis in the rat (8), congestive heart failure in man (11), Laënnec's cirrhosis in man (12), and the ascites accompanying the narrowing of the inferior vena cava in the dog (13). In all four of these situations, there is evidence for an increased secretory activity of the renal juxtaglomerular cells. Moreover, in all four situations, one can reasonably conclude that there is a tendency to underdistention of the whole arterial tree, including the renal arterial bed (8). There is also evidence for an intrinsic regulation entirely within the kidney that relates arterial perfusion pressure to the excretion of sodium. Increasing perfusion pressure leads to a sodium diuresis, despite the absence of a measurable increase in the rate of sodium filtration (9). Decreasing perfusion pressure can result in an increased tubular reabsorption of sodium, again without a measurable decrease in glomerular filtration (4). Such experiments seem to indicate that the level of renal perfusion pressure influences the rate of sodium reabsorption by some portion of the renal tubule. Furthermore, increasing the renal perfusion pressure causes a fairly rapid reduction in the granularity of the juxtaglomerular cells (14). Quite conceivably, a change in the distention of the renal arterial bed causes a change in the rate of secretion of the juxtaglomerular cells, and the resulting alteration in the concentration of juxtaglomerular humoral substances within the kidney causes a change in the reabsorption of sodium by certain segments of tubular cells. 
With this relationship in mind, we set up the following experiment to discover whether or not changing the distention of the renal arterial bed by altering perfusion pressure would influence the ability of distal tubular cells to remove sodium from the tubular urine.

\section{Methods}

In these experiments, a rat without either kidneys or adrenals (the "perfusing" rat) provided blood for the continuous perfusion of an isolated kidney from another rat. The rats used were all normal rats of the Holtzman strain weighing about $400 \mathrm{~g}$. The kidney and adrenal were removed from one side of the perfusing rat at least 2 weeks before an experiment. On the day of the experiment, the perfusing rat was anesthetized with ether and then given $3 \mathrm{mg}$ of cortisone acetate intramuscularly as well as $0.4 \mathrm{mg}$ of atropine and $5 \mathrm{mg}$ of pentobarbital sodium (Nembutal) subcutaneously. The remaining kidney and adrenal were removed from this rat about 1 hour before the actual beginning of the experiment. After the incision was sewn up, the trachea, carotid artery, jugular vein, femoral artery, and femoral vein were cannulated. From then on, this rat was anesthetized with a gas mixture containing $80 \%$ nitrous oxide and $20 \%$ oxygen.

At the same time that the perfusing rat was being prepared, a normal kidney was isolated from another rat. Eventually this normal kidney was excised, placed in a warming box, and hooked into the circulation of the perfusing rat, artery-to-artery and vein-to-vein, with polyethylene tubing for the connections. During the entire procedure for connecting the isolated kidney to the circulation of the perfusing rat, the kidney underwent only three 30 -second periods of ischemia. The ureter of the isolated kidney was connected to the femoral vein of the perfusing rat with polyethylene tubing so that all urine would be returned to the vascular system. This was to keep the volume of fluid and the amount of mannitol in the total preparation relatively constant.

The tubing that connected the carotid artery of the perfusing rat to the renal artery of the isolated kidney went through a Sigmamotor pump. By utilizing different settings of this pump, we were able to perfuse the isolated kidney at various levels of inflow pressure. Furthermore, an additional infusion pump ${ }^{1}$ connected through a sidearm to the jugular vein provided a steady infusion of a $25 \%$ mannitol solution. The rate of blood flow through the isolated kidney was measured directly. A schema of the preparation is given in Figure 1.

After the foregoing connections had been completed, a 55-minute "preparatory" perfusion of the isolated kidney was begun. In the experiments of Series I and II, the isolated kidney was perfused at $170 \mathrm{~mm} \mathrm{Hg}$ during this preparatory period. In the experiments of Series III, the isolated kidney was perfused at only $100 \mathrm{~mm} \mathrm{Hg}$

\footnotetext{
${ }^{1}$ Harvard Apparatus, Dover, Mass.
}

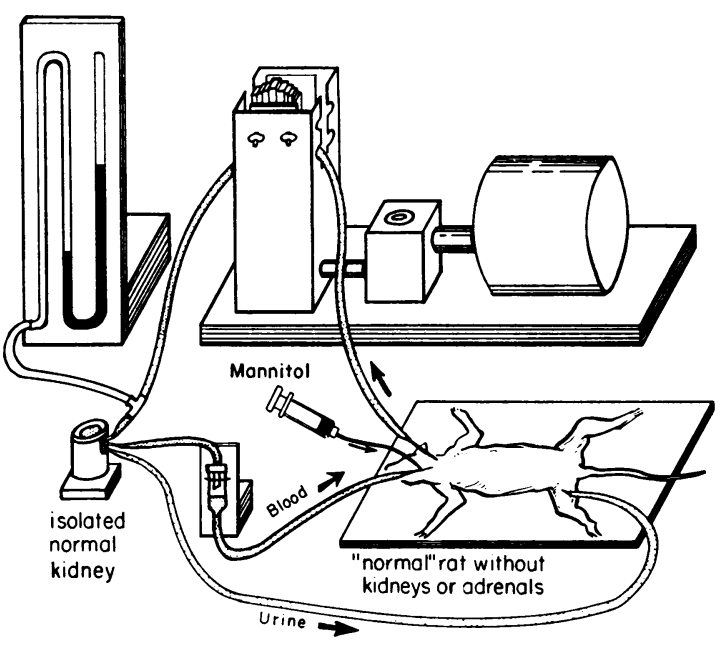

Fig. 1. Diagram of the arrangement of various COMPONENTS DURING THE PREPARATORY PERIOD OF A STOPFLOW EXPERIMENT.

during the preparatory period. During this 55-minute period in all three series, mannitol was steadily injected into the perfusing rat at the rate of $44.5 \mathrm{mg}$ per minute.

At the end of the 55-minute preparatory period, the ureter was abruptly clamped for the stop-flow procedure. At the same time, the infusion of mannitol was abruptly stopped, and an infusion of $.89 \%$ saline was begun at the rate of $.19 \mathrm{ml}$ per minute. The ureter distal to the clamp was then disconnected from the femoral vein and attached to an 18-foot length of polyethylene tubing (size PE 20). The pressure in the ureter was monitored with a Statham strain gauge. The ureteric pressure rose quickly after the ureter had been clamped until a plateau was reached about $3 \frac{1}{2}$ minutes after clamping in both Series I and Series III. The clamp was kept on the ureter for exactly 8 minutes after this plateau had been reached. In the experiments of Series I, the isolated kidney was perfused at $170 \mathrm{~mm} \mathrm{Hg}$ during this stop period. In both Series II and III, however, the isolated kidney was perfused at only $100 \mathrm{~mm} \mathrm{Hg}$ during the stop period.

At the end of the 8-minute stop period, the clamp on the ureter was abruptly released, and urine was allowed to gush out into the polyethylene tubing. To facilitate a rapid passage of urine into the tubing, the pressure perfusing the kidney was always brought up to $170 \mathrm{~mm} \mathrm{Hg}$ just as the clamp was released. A summary of the perfusion pressures in the three experimental series is given in Table I.

In Series I, the average pressure in the ureter was $85 \mathrm{~mm} \mathrm{Hg}$ just after the pressure plateau had been reached after applying the clamp. In Series III the average pressure in the ureter was $41 \mathrm{~mm} \mathrm{Hg}$ after this plateau had been reached. In Series II, the ureter was clamped while the isolated kidney was being perfused at $170 \mathrm{~mm} \mathrm{Hg}$. In this series, when the intraureteric pressure had risen to $41 \mathrm{~mm} \mathrm{Hg}$, the pump setting was 
TABLF; I

Pressures used to perfuse the isolated kidney

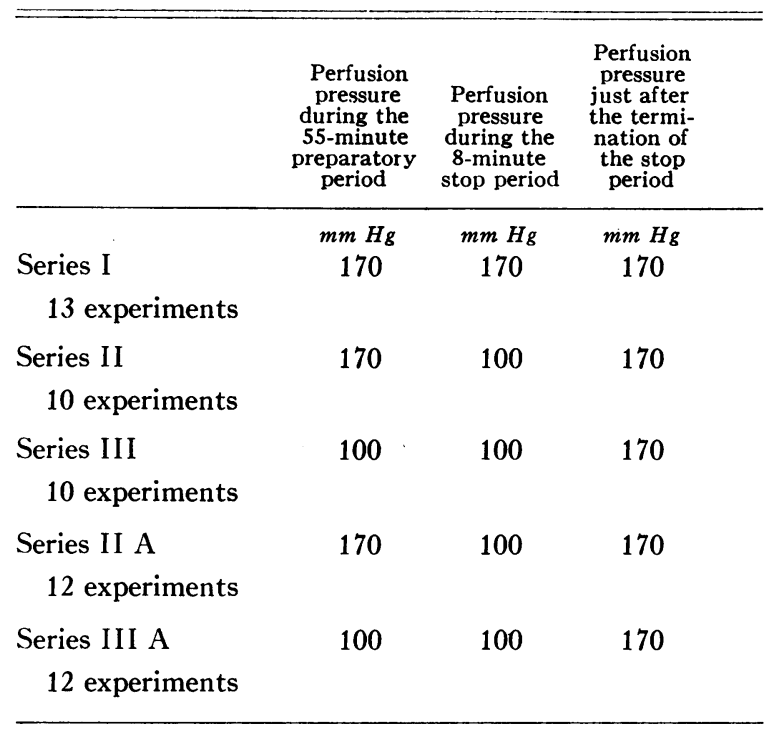

abruptly changed so that the isolated kidney was perfused at only $100 \mathrm{~mm} \mathrm{Hg}$. At this point, at which the perfusing pressure and the ureteric pressure were in equilibrium, the 8-minute stop period commenced for this series. Once the ureteral plateau pressure had been reached after clamping, it remained constant at the plateau level in our rats, even for as long as 40 minutes if the ureteral clamp was left on that long.

After the urine had been collected in the polyethylene tubing, the tubing was cut into successive $10-\mu 1$ segments, and the content of each segment was quantitatively diluted for subsequent sodium analysis by flame photometry. The polyethylene tubing was quite constant in diameter so that any given segment contained between 9.8 and $10.2 \mu 1$. The error relating to the flame photometry was seldom greater than $2 \%$.

After these initial experiments, two additional series of experiments were performed to determine whether there had been an inordinate amount of mixing of the various segments of urine as they passed down the polyethylene tubing. The later experiments were identical to the original Series II and III except that at the end of the stop period, each drop of urine was collected

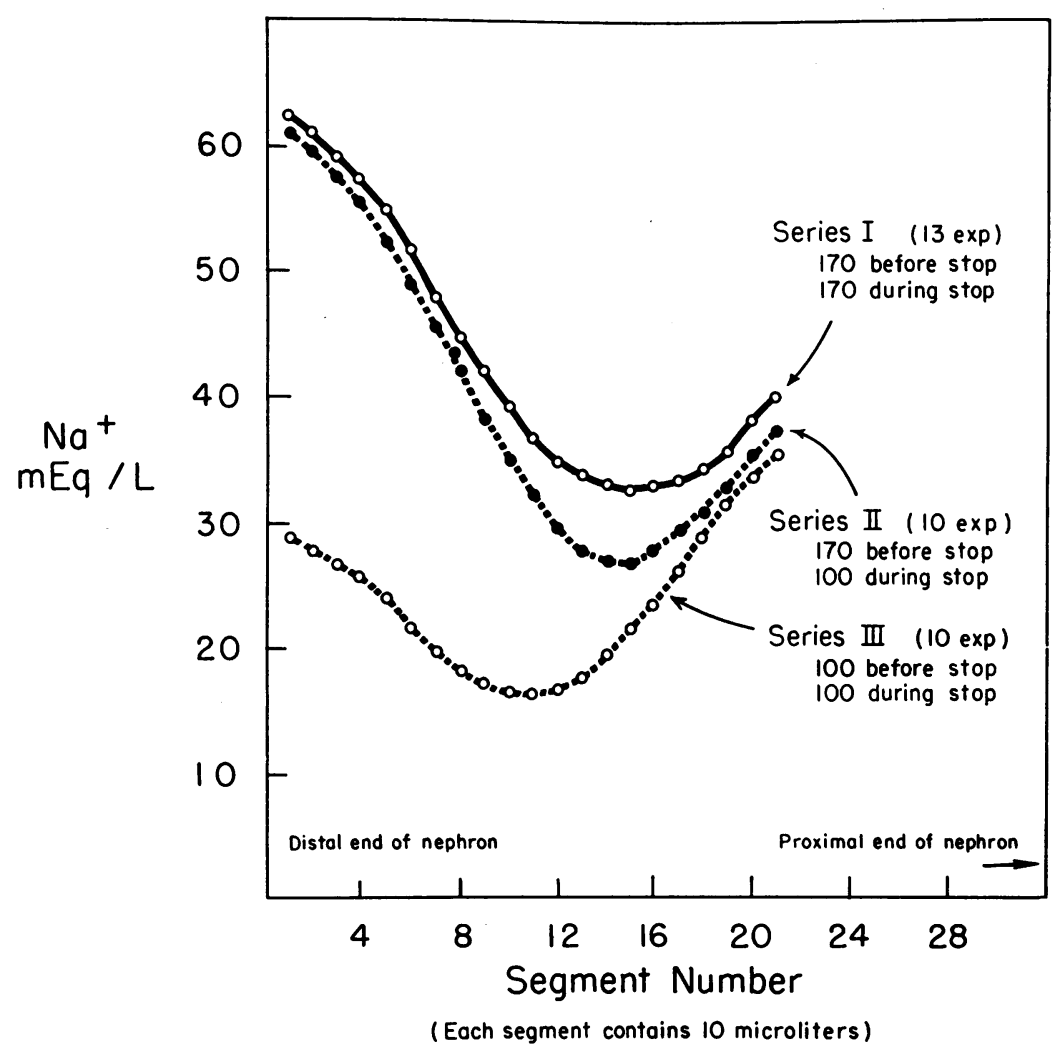

Fig. 2. Stop-FLOW EXPERIMENTS PERFORMED WHILE PERFUSING ISOLATED KIDNeYS AT VARIOUS LEVELS OF PRESSURE. Each of the lines on the graph gives an average of all stop-flow curves in a given series of experiments. The average sodium concentration of the various segments is shown on the ordinate. Segment no. 1 contains the first urine to appear after the ureteral clamp was released at the end of the stop period. 


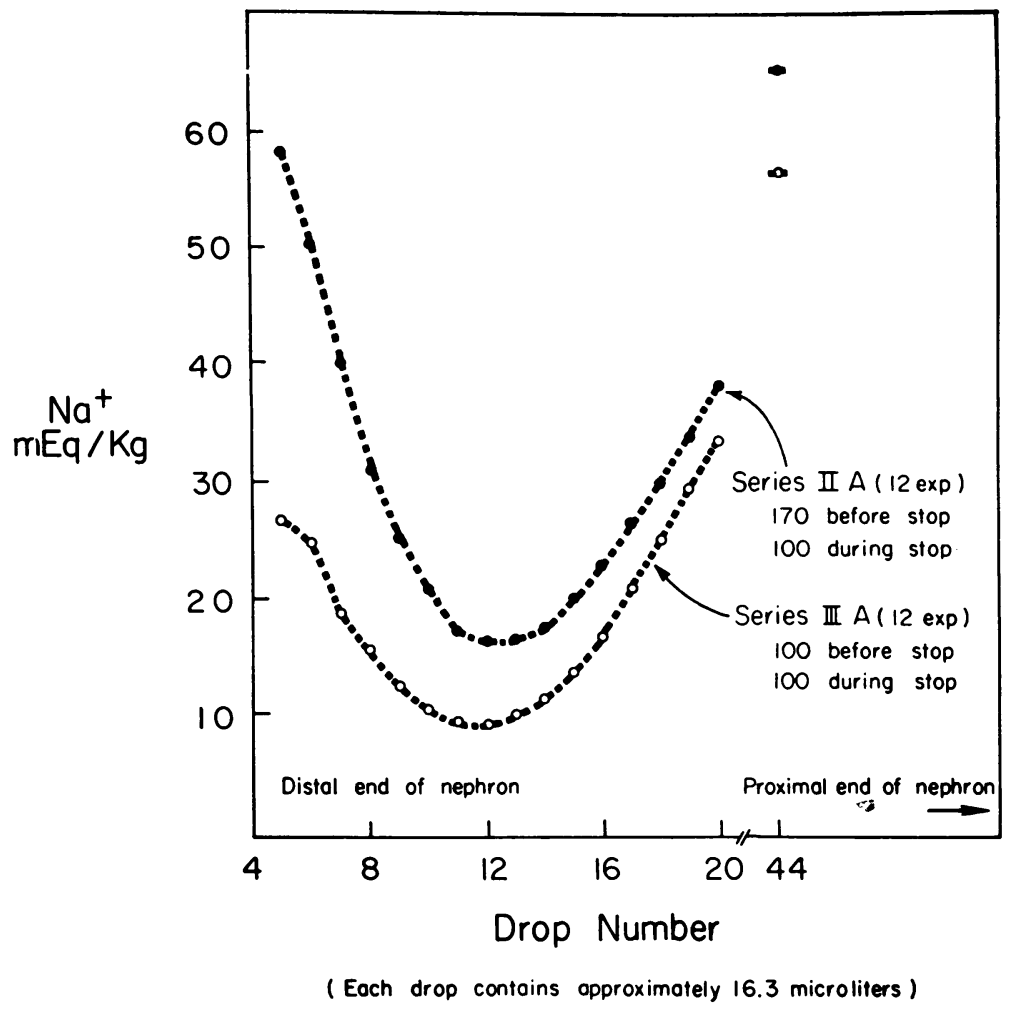

Fig. 3. SeE Legend for Figure 2.

in a separate test tube as it issued from the ureter, instead of allowing it to flow into polyethylene tubing. The first four drops could not always be collected precisely; therefore the analyses begin with the fifth drop collected after the stop period. After the first twenty drops had been collected individually, the next twentythree drops were collected together in a weighed tube. The weight of these drops gave us the average weight of a drop of urine for each isolated kidney. After this collection, the forty-fourth drop was individually collected. All the drops collected individually were analyzed for their sodium concentration, expressed as $\mathrm{mEq}$ per $\mathrm{kg}$ of urine. These two additional series are designated as Series II A and III A, since they are similar in most ways to the original Series II and III (see Table I).

When the sodium concentrations in the successive segments of polyethylene tubing or in the successive drops were plotted, we found the usual drop in sodium concentration in the segments representing the distal part of the nephron in all five series (see Figures 2 and 3 ). This characteristic drop has been observed previously in both the $\operatorname{dog}(15)$ and the rat (16). The drop occurs because the cells in the distal part of the nephron are able to pump sodium out of the tubular urine that lies stationary opposite them during the stop period. Once a steady-state equilibrium has been attained in the tubular urine in these stop-flow studies, the minimal concen- tration of sodium on the sodium curve is a measure of the maximal ability of these cells to provide a net transport of sodium against a concentration gradient. Therefore finding whether or not equilibrium had indeed been achieved during our usual 8-minute stop period was important.

In ten separate studies we found that this sodium curve does reach an equilibrium concentration sometime during the first 6 minutes of the stop period, even with perfusion pressures at $170 \mathrm{~mm} \mathrm{Hg}$. In each of these ten studies, two stop-flows were performed successively, with a 25-minute interval between the end of the first stop period and the beginning of the second. To compensate for the fluid lost during the urine collection, $0.5 \mathrm{ml}$ of physiological saline was given intravenously to the perfusing rat at the end of the first stop-flow. In five of the experiments, a 6-minute stop period was followed by an 8-minute stop period. In the other five experiments, the 8-minute stop period was followed by the 6-minute stop. In Figure 4 the results of this comparison are shown. Each line on the figure represents the mean of 10 stop-flow studies; a stop period of only 6 minutes produces a curve of sodium concentrations with a low point just as low as the stop period of 8 minutes. Presumably, by 6 minutes, a steady state is reached in which the sodium pumped out is just balanced by that leaking back into the tubular urine. By using a stop period of 8 minutes in our experiments, 


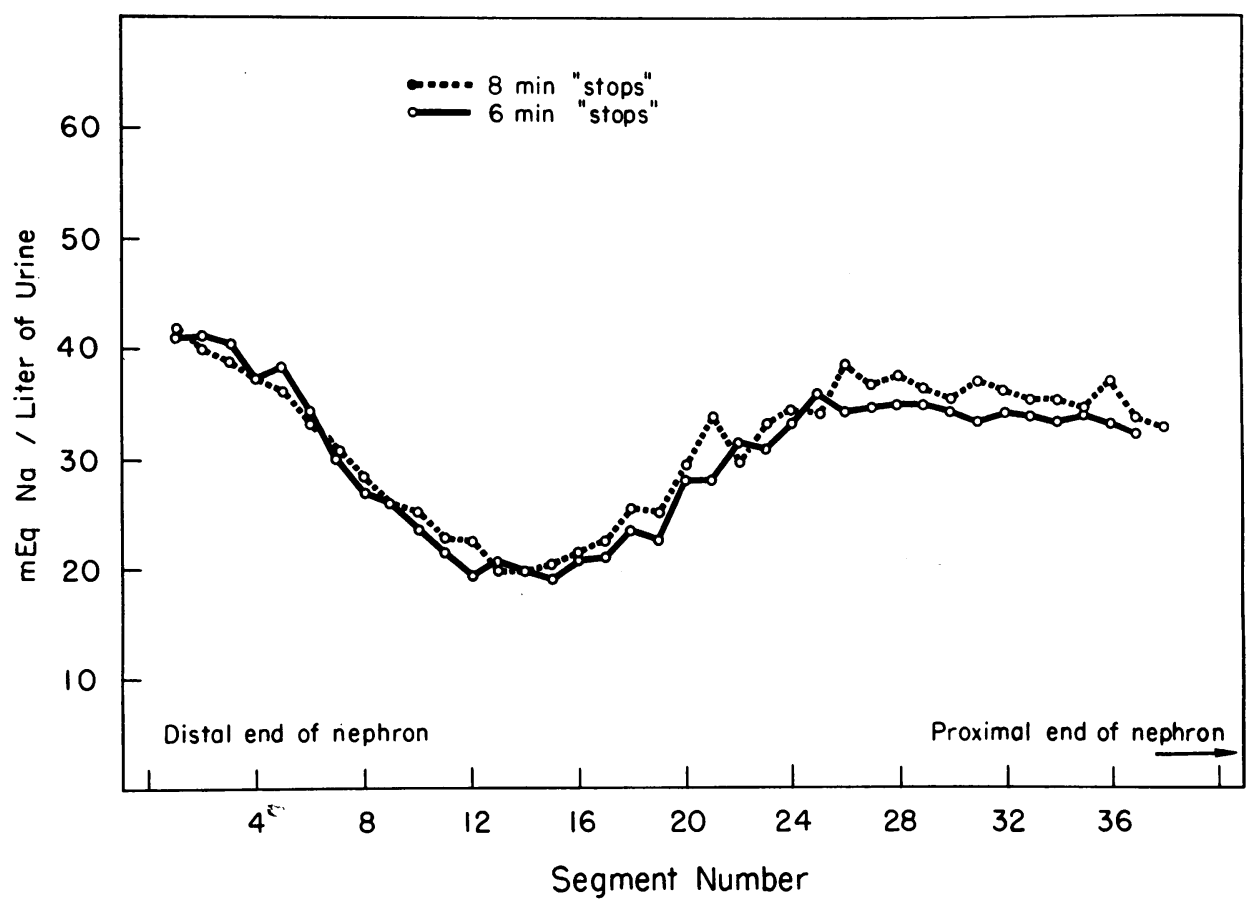

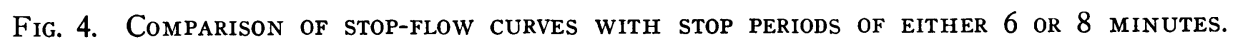
Two successive stop-flow procedures, one with a 6-minute stop and one with an 8-minute stop, were performed on ten rats. One curve is an average of the ten 6-minute stops; the other curve is an average of the ten 8-minute stops. Sodium concentration is given on the ordinate.

we allowed ample time for a minimal sodium concentration to be attained. This is not surprising, since the stop-flow studies of Williamson, Skulan, and Shideman in the rat indicate that equilibrium for sodium in the distal part of the nephron is virtually attained within $120 \mathrm{sec}-$ onds after clamping the ureter (16). The minimal sodium concentration in this study was somewhat lower than that of Series I. These groups cannot, however, be compared with validity, since the schedule of mannitol infusion was considerably different in the two studies.

The studies in the three original series were carried out in round robin, so that all three series were completed about the same time. This was also done with the two subsequent series. This order prevented any subtle change in conditions or technique from affecting the comparison of the groups.

\section{Results}

Minimal concentrations on the sodium curve. Since the minimal sodium concentration in a given stop-flow experiment represents the maximal ability of the distal tubular cells to achieve a net transport of sodium against a gradient, these minimal concentrations were averaged for the original three series (see Table II and Figure 2). In the experiments of Series I, the minimal sodium con- centrations for 13 experiments averaged 31.4 $\mathrm{mEq}$ per L. In Series II, the minimal concentrations averaged $25.4 \mathrm{mEq}$ per $\mathrm{L}$. These two means were not significantly different $(p=.13)$. In Series III, however, the minimal concentrations averaged only $14.3 \mathrm{mEq}$ per $\mathrm{L}$. This average was significantly lower than that of Series I $(p<$ $.0001)$ or Series II $(p<.0001)$.

This same comparison was made for the two subsequent series, II A and III A (see Table III and Figure 3). In Series II A, the minimal sodium concentrations averaged $13.7 \mathrm{mEq}$ per $\mathrm{kg}$; in Series III A, the minimal concentrations averaged $7.9 \mathrm{mEq}$ per $\mathrm{kg}$. These means were significantly different $(\mathrm{p}=.0003)$. The minimal sodium concentrations were about $45 \%$ lower in Series II A and III A than in Series II and III, respectively. Nevertheless, the ratios were approximately the same, the average sodium minimum of Series II being about $78 \%$ greater than that of Series III, the average sodium minimum of Series II A, about $74 \%$ greater than that of Series III A. 
TABLE II

The lowest concentration of sodium on the stop-flow curve for experiments of the original three series*

\begin{tabular}{lrrr}
\hline \hline & Series I & Series II & Series III \\
\hline & 51.9 & 39.7 & 18.6 \\
& 13.0 & 29.9 & 11.7 \\
& 38.4 & 26.2 & 9.2 \\
& 18.2 & 29.8 & 18.2 \\
& 16.4 & 23.9 & 8.3 \\
& 26.5 & 23.3 & 10.2 \\
& 22.3 & 16.8 & 12.8 \\
& 31.2 & 25.6 & 19.8 \\
& 34.8 & 21.2 & 15.0 \\
Mean $\dagger$ & 41.3 & 17.9 & 19.4 \\
SD & 29.4 & & \\
& 50.3 & & \\
& 34.8 & & \\
& 31.4 & 25.4 & 14.3 \\
& \pm 11.7 & \pm 6.3 & \pm 4.2
\end{tabular}
liter.

* Concentrations are expressed as milliequivalents per

$\dagger p$ value of the difference between the means of Series I and III : $<.0001$. $p$ value of the difference between the means of Series II and III : $<.0001$. p value of the difference between the means of Series I and II $:=.13$

Relative effects of renal blood flow and renal perfusion pressure. In general, the kidneys with the higher perfusion pressure during the preparatory period had a higher rate of blood flow. Thus, a difference in either pressure or flow could have been the critical stimulus for producing the different levels of net sodium transport in the distal part of the nephron in Series I and II versus Series III and in Series II A versus Se-
TABLE III

The lowest concentration of sodium on the stop-flow curve for experiments of the subsequent two series*

\begin{tabular}{rrr}
\hline \hline & Series II A & Series III A \\
\hline & 16.1 & 10.9 \\
11.1 & 3.9 \\
10.1 & 6.9 \\
10.4 & 5.9 \\
9.1 & 6.9 \\
10.7 & 8.2 \\
& 21.3 & 17.9 \\
& 16.2 & 10.3 \\
& 21.6 & 6.8 \\
& 13.1 & 5.5 \\
& 11.8 & 6.1 \\
Mean $\dagger$ & 13.0 & 5.2 \\
SD & 13.7 & 7.9 \\
& \pm 4.0 & \pm 3.6
\end{tabular}

* Concentrations are expressed as milliequivalents per kilogram.

$\dagger \mathrm{p}$ value of the difference between the means of Series II $\mathrm{A}$ and III $\mathrm{A}:=.0003$.

ries III A. To get a partial answer to this question, we compared the six kidneys with the highest native resistance to flow in both Series I and Series II with the six kidneys having the lowest native resistance to flow in Series III. By this means, we could compare three series, all with about the same average rate of renal blood flow during the preparatory period but with varying levels of perfusion pressure. These rates of blood flow and the minimal sodium concentrations on the stop-flow curves are given in Table IV. The mini-

TABLE IV

The lowest sodium concentration on the stop-flow curves of kidneys with comparable rates of blood flow during the preparatory period

\begin{tabular}{|c|c|c|c|c|c|c|}
\hline \multicolumn{3}{|c|}{ Series I } & \multicolumn{2}{|c|}{ Series II } & \multicolumn{2}{|c|}{ Series III } \\
\hline & $\begin{array}{l}\text { te of renal } \\
\text { flow }\end{array}$ & $\begin{array}{l}\text { Lowest } \\
\text { sodium } \\
\text { concentration } \\
\text { on the stop- } \\
\text { flow curve }\end{array}$ & $\begin{array}{l}\text { Rate of } \\
\text { renal blood } \\
\text { flow }\end{array}$ & $\begin{array}{l}\text { Lowest } \\
\text { sodium } \\
\text { concentration } \\
\text { on the stop- } \\
\text { flow curve }\end{array}$ & $\begin{array}{l}\text { Rate of } \\
\text { renal blood } \\
\text { flow }\end{array}$ & $\begin{array}{l}\text { Lowest } \\
\text { sodium } \\
\text { concentration } \\
\text { on the stop- } \\
\text { flow curve }\end{array}$ \\
\hline & $\mathrm{ml} / \mathrm{min}$ & $m E q / L$ & $\mathrm{ml} / \mathrm{min}$ & $m E q / L$ & $\mathrm{ml} / \mathrm{min}$ & $m E q / L$ \\
\hline & $\begin{array}{l}1.9 \\
2.0 \\
2.3 \\
3.9 \\
4.1 \\
4.1\end{array}$ & $\begin{array}{l}41.3 \\
13.0 \\
31.2 \\
34.8 \\
51.9 \\
50.3\end{array}$ & $\begin{array}{l}3.6 \\
3.9 \\
4.2 \\
4.1 \\
3.6 \\
4.5\end{array}$ & $\begin{array}{l}26.2 \\
21.2 \\
29.9 \\
39.7 \\
23.4 \\
16.7\end{array}$ & $\begin{array}{l}3.9 \\
3.9 \\
3.3 \\
3.7 \\
3.1 \\
2.2\end{array}$ & $\begin{array}{r}9.2 \\
10.3 \\
19.4 \\
8.3 \\
18.6 \\
12.7\end{array}$ \\
\hline Mean* & 3.1 & 37.1 & 4.0 & 26.2 & 3.4 & 13.1 \\
\hline SD & & \pm 14.3 & & \pm 7.9 & & \pm 4.8 \\
\hline
\end{tabular}

* $\mathrm{p}$ value of the difference between the sodium means of Series I and III : <.0001. p value of the difference between the sodium means of Series II and III : =.0005. p value of the difference between the sodium means of Series I and II : $=.1$. 
TABLE $V$

The lowest sodium concentration on the stop-flow curves of kidneys with comparable rates of blood flow during the preparatory period

\begin{tabular}{|c|c|c|c|c|}
\hline \multicolumn{3}{|c|}{ Series II A } & \multicolumn{2}{|c|}{ Series III A } \\
\hline \multicolumn{2}{|c|}{$\begin{array}{l}\text { Rate of renal } \\
\text { blood flow }\end{array}$} & $\begin{array}{l}\text { Lowest sodium } \\
\text { concentration } \\
\text { on the stop- } \\
\text { flow curve }\end{array}$ & $\begin{array}{l}\text { Rate of renal } \\
\text { blood flow }\end{array}$ & $\begin{array}{l}\text { Lowest sodium } \\
\text { concentration } \\
\text { on the stop- } \\
\text { flow curve }\end{array}$ \\
\hline & $\mathrm{ml} / \mathrm{min}$ & $m E q / k g$ & $m l / m i n$ & $m E q / k g$ \\
\hline & $\begin{array}{l}4.0 \\
5.5 \\
5.6 \\
5.8 \\
6.0 \\
6.1\end{array}$ & $\begin{array}{r}21.3 \\
21.6 \\
10.7 \\
11.8 \\
16.2 \\
9.1\end{array}$ & $\begin{array}{l}4.8 \\
5.0 \\
5.1 \\
5.1 \\
5.9 \\
6.2\end{array}$ & $\begin{array}{r}5.9 \\
6.9 \\
6.9 \\
6.1 \\
6.8 \\
10.9\end{array}$ \\
\hline Mean* & 5.5 & 15.1 & 5.4 & 7.2 \\
\hline $\mathrm{SD}$ & & \pm 5.0 & & \pm 1.7 \\
\hline
\end{tabular}

${ }^{*} \mathrm{p}$ value of the difference between the sodium means of Series II A and III A: $=.001$.

mal sodium concentration in Series I and II averaged $37.1 \mathrm{mEq}$ per $\mathrm{L}$ and $26.2 \mathrm{mEq}$ per $\mathrm{L}$, respectively, whereas the minimal sodium concentration in Series III averaged $13.1 \mathrm{mEq}$ per L.

This same type of comparison was made for Series II A and III A and is shown in Table V. The minimal sodium concentration in Series II A averaged $15.1 \mathrm{mEq}$ per $\mathrm{kg}$, whereas the minimal sodium concentration in Series III A averaged $7.2 \mathrm{mEq}$ per $\mathrm{kg}$. Thus, when kidneys with the same rate of blood flow were compared, the series with the preparatory perfusion at $100 \mathrm{~mm} \mathrm{Hg}$ achieved a greater net transport of sodium in the distal nephron than the series with a preparatory perfusion at $170 \mathrm{~mm} \mathrm{Hg}$.

Influence of urine flow rate. In general, the rate of urine flow during the preparatory period was faster in Series I and II than in Series III.
Such a diuresis increases the pressure in the distal convoluted tubules and proximal portion of the collecting ducts (17). This might have an effect on the sodium concentrations in a subsequent stop-flow procedure. Therefore, we compared the four experiments with the lowest urine flows in Series II to the four experiments in Series III with the highest urine flows. These two particular series were compared because they had similar ureteral pressures during the stop period and also had some overlapping in the rate of urine flow. As seen in Table VI, the urine flow during the preparatory period averaged $198 \mu l$ per minute in Series II and 161 in Series III; the urine flow was $23 \%$ greater in Series II. The lowest points on the sodium curve averaged $26.2 \mathrm{mEq}$ per $\mathrm{L}$ in Series II and $12.1 \mathrm{mEq}$ per L in Series III. Thus, in these particular experiments the prepara-

TABLE VI

The lowest sodium concentration on the stop-flow curves of kidneys with fairly comparable rates of urine flow during the preparatory period*

\begin{tabular}{|c|c|c|c|c|}
\hline \multicolumn{3}{|c|}{ Series II } & \multicolumn{2}{|c|}{ Series III } \\
\hline \multicolumn{2}{|c|}{ Rate of urine flow } & $\begin{array}{l}\text { Lowest sodium } \\
\text { concentration } \\
\text { on the stop- } \\
\text { flow curve }\end{array}$ & $\begin{array}{l}\text { Rate of } \\
\text { urine flow }\end{array}$ & $\begin{array}{l}\text { Lowest sodium } \\
\text { concentration } \\
\text { on the stop- } \\
\text { flow curve }\end{array}$ \\
\hline & $\mu l / \min$ & $m E q / L$ & $\mu l / \min$ & $m E q / L$ \\
\hline & $\begin{array}{l}163 \\
189 \\
220 \\
220\end{array}$ & $\begin{array}{l}40.8 \\
21.2 \\
26.2 \\
16.8\end{array}$ & $\begin{array}{l}147 \\
240 \\
110 \\
147\end{array}$ & $\begin{array}{r}11.7 \\
9.2 \\
8.3 \\
19.4\end{array}$ \\
\hline Mean $\dagger$ & 198 & 26.2 & 161 & 12.1 \\
\hline
\end{tabular}

* Only Series II and III are shown, since they had the same ureteral pressure during the stop period.

$\dagger \mathrm{p}$ value of the difference between the sodium means of Series II and III $:=.05$ (using $t$ table). 
tory urine flows were not greatly increased in Series II over Series III, yet, the sodium curves derived from the stop-flow maneuver were quite typical of their group as a whole. This result would suggest that the level of perfusion pressure has a more decisive influence on the subsequent stop-flow curves than the rate of urine flow during the preparatory period.

\section{Discussion}

Under the conditions of our experiment, a steady-state equilibrium for sodium concentration in the distal nephron is seemingly attained after 8 minutes of the stop period. Such an equilibrium is the result of the rate at which sodium is pumped out of the distal urine and the rate at which it leaks back. This result is a measure of the net transport of sodium out of the distal urine. When the preparatory perfusion is at $170 \mathrm{~mm} \mathrm{Hg}$ as in Series I and II, the maximal net transport of sodium against a concentration gradient brings the concentration of sodium down to an average level of only $31 \mathrm{mEq}$ per $\mathrm{L}$ and $25 \mathrm{mEq}$ per $\mathrm{L}$, respectively, in the two groups. On the other hand, when the preparatory perfusion is at 100 $\mathrm{mm} \mathrm{Hg}$ as in Series III, the maximal net transport of sodium is capable of bringing the concentration of sodium down to an average of 14 $\mathrm{mEq}$ per $\mathrm{L}$ in the distal urine. This difference was highly significant, as was the difference between Series II A and III A.

In Series II, the infusion pressure was $170 \mathrm{~mm}$ $\mathrm{Hg}$ during the preparatory phase but only 100 $\mathrm{mm} \mathrm{Hg}$ during the stop period. The sodium concentration curves in this group were similar to those of Series I, however, rather than to those of Series III. The results in Series II thus indicate that the infusion pressure during the preparatory period has a more decisive influence on the stopflow curve than the pressure during the stop period. The difference in net sodium transport between Series I and II on the one hand and Series III on the other hand cannot be related to a changing rate of secretion of aldosterone, since there was no adrenal tissue anywhere in the system. Since the second adrenal gland had been removed only 2 hours before the stop-flow procedure, a low plasma concentration of aldosterone undoubtedly remained during the preparatory pe- riod. The varying perfusion pressures might have affected the uptake and distribution of this aldosterone within the isolated kidney. None of these kidneys had any nerve connections with the central nervous system; therefore this type of influence cannot account for differences in net transport.

Taylor and Ullmann have shown that the movement of fluid in the distal $40 \%$ of the nephron $11 \frac{1}{2}$ minutes after ureteral clamping is very, very slow indeed (18). Moreover, Rector (19) has described experiments in which minimal concentrations of sodium are attained in the urine of the rat even with a mannitol diuresis, indicating that the tubular cells of the rat are capable of reaching an equilibrium concentration with great rapidity. In Series II and II A, the perfusion pressure was only $100 \mathrm{~mm} \mathrm{Hg}$ during the stop period, the same as that of Series III and III A, so that there should have been no great difference in the rate of movement of distal tubular urine between these respective groups. Nevertheless, the net transport of sodium in Series II and II A was considerably less than that in Series III and III A.

When Series I and Series III are compared during the stop period, there are some obvious differences in the state of the kidney. The medullary blood flow in Series I would be generally higher than that of Series III. Furthermore, the intraluminal pressure of the tubules of Series I was undoubtedly greater than that in the tubules of Series III. Such factors could very well influence a stop-flow pattern. In Series II and II A, however, the perfusing pressure during the stop period was the same as that of Series III and III A; therefore the medullary blood flow and the distention of the tubules should have been the same in these two groups. Nevertheless, the net sodium transport was considerably less in Series II and II A, making unlikely a significant influence of these factors on the results.

With a preparatory perfusion at $170 \mathrm{~mm} \mathrm{Hg}$, there is usually a diuresis of sodium and water. This accounts for the great difference in sodium concentration in the most distal segment of urine when Series III is compared to Series I and II, as the sodium concentration in the most distal segment reflects the concentration in free-flowing urine. Thus, at the moment when the ureter was clamped, there was more sodium contained in the 
distal tubules of Series I and II than in those of Series III. This difference, however, should not affect the final sodium concentrations in the stopflow curve, since, even with perfusions at $170 \mathrm{~mm}$ $\mathrm{Hg}$, maximal net transport of sodium is achieved by 6 minutes of the stop period. Thus, with the 8 -minute stop period of our experiments, more than enough time is provided to reach an equilibrium in net transport, even in Series I, II, and II A.

Since there was a diuresis during the preparatory phase of Series I, II, and II A, the distal convoluted tubules and the proximal portion of collecting ducts were undoubtedly distended with a greater pressure in these three series during the preparatory period than that of Series III and III A (17). Then the ureteral clamp was applied, and in Series II, II A, III, and III A, the distending pressure should have been equal for a period of at least 8 minutes. The distention of the distal tubules of Series II and II A during the preparatory infusion could conceivably produce a lingering effect on the net transport of sodium during the stop period. If this lingering effect continued for 6 minutes and then abated, there would still be sufficient time during the final 2 minutes of the stop period to achieve an equilibrium level of net sodium transport. Moreover, in the experiments shown in Table VI, the urine flow in Series II is only slightly greater than that in Series III; the distal intratubular pressure would be only slightly greater (17). Yet, in these experiments the net sodium transport in Series II is considerably less than that of Series III, suggesting that a difference in distal intratubular pressure is not an important factor.

The main difference between the experiments of Series II and II A and Series III and III $A$ is the level of perfusing pressure during the 55minute preparatory period. This difference in perfusing pressure is somehow registered and induces fairly large changes in the net distal transport of sodium. The difference in net sodium transport for these groups is probably not, however, the result of pressure and flow differences during the stop period. This induces the authors to speculate that a difference in the concentration of humoral substances within the kidney brings about the changes in net sodium transport. Such humoral substances may well be generated within the kidney. As mentioned above, the juxtaglomerular apparatus would be a likely sensing device for detecting the changes in perfusion pressure. Once the signal was detected, the granular cells and the macula densa cells of the juxtaglomerular apparatus would appropriately change their rate of secretion. The level of humoral substances so generated could influence directly the distal tubular cells and alter their net transport of sodium. It is also remotely possible that humoral substances from the juxtaglomerular apparatus could act on some distant organ in the perfusing rat other than the adrenal and induce that organ to secrete more or less of some humoral substance that would influence the net transport of sodium in the distal tubules and collecting ducts. As suggested above, such a mechanism could play a prominent part in the various sodiumretaining syndromes that are associated with underdistention of the renal arterial bed. It could provide an additional factor that would act in concert with aldosterone and with the rate of glomerular filtration to regulate the renal excretion of sodium. This mechanism would ordinarily be geared perfectly to aldosterone, since the renin secreted by the juxtaglomerular apparatus causes the elaboration of angiotensin, which is probably the most potent stimulator and regulator of aldosterone secretion $(13,20-23)$.

Such mechanisms might also partly explain the phenomenon of the Howard test (24). When one renal artery is partially narrowed in man, arterial hypertension usually results, and the sodium concentration in the urine of the ischemic kidney is characteristically less than that of the contralateral kidney. The rate of sodium filtration is usually less in the ischemic kidney, and a considerably greater fraction of the filtered sodium is reabsorbed by its tubules. The slower rate of urine flow in the tubules of the ischemic kidney undoubtedly accounts for part of the increased percentage of sodium reabsorption in that kidney. In these patients, however, the two kidneys have greatly differing levels of perfusion pressure. If the level of perfusion pressure affects the net transport of sodium out of the distal urine in man as it does in the rat, this factor would also contribute to the relatively more avid reabsorption of sodium in the tubules of the ischemic kidney. 


\section{Summary}

After a 55-minute perfusion of isolated kidneys at $170 \mathrm{~mm} \mathrm{Hg}$, the tubular cells in the distal part of the nephron have a relatively limited ability to effect a net transport of sodium out of the distal tubular urine in a stop-flow situation. In two series of experiments utilizing this high perfusion pressure, the lowest concentration of sodium in the stop-flow studies averaged $31 \mathrm{mEq}$ per $\mathrm{L}$ and $25 \mathrm{mEq}$ per L, respectively. Conversely, after a 55 -minute perfusion at $100 \mathrm{~mm} \mathrm{Hg}$, the distal tubular cells have a relatively enhanced ability to effect a net transport of sodium out of the distal urine. In a series of experiments utilizing this lower perfusion pressure, the lowest concentration of sodium in the stop-flow studies averaged 14 $\mathrm{mEq}$ per $\mathrm{L}$. In a subsequent comparison using a different stop-flow method, the high perfusion pressure resulted in an average minimal sodium concentration of $13.7 \mathrm{mEq}$ per $\mathrm{kg}$, whereas the low perfusion pressure produced an average minimal sodium concentration of $7.9 \mathrm{mEq}$ per $\mathrm{kg}$. This difference in net transport of sodium seems related more to the perfusion pressure than to the rate of blood or urine flow. Renal hemodynamics and the rate of flow in the renal tubules during the stop period cannot account for the difference. The difference in net sodium transport does not depend upon a changing rate of aldosterone secretion or upon neurogenic reflexes from the central nervous system. Apparently, changing the distention of the renal arterial bed by altering perfusion pressure somehow influences the ability of distal tubular cells to effect a net transport of sodium, underdistention increasing transport and overdistention decreasing it.

The authors speculate that the varying levels of perfusion pressure are sensed by the granular juxtaglomerular cells, acting as stretch receptors. The juxtaglomerular apparatus (granular cells plus macula densa cells) then appropriately responds by changing its rate of secretion. The concentration of these secretory substances in the fluids of the kidney subsequently regulates the net transport of sodium in the distal convoluted tubule and collecting duct, acting in concert with the tissue levels of aldosterone. This mechanism is probably active in various sodium-retaining situations associated with underdistention of the arterial tree. It may also partially explain the phenomenon of the Howard test.

\section{References}

1. Epstein, F. H., R. S. Post, and M. McDowell. The effect of an arteriovenous fistula on renal hemodynamics and electrolyte excretion. J. clin. Invest. 1953, 32, 233.

2. Rosenbaum, J. D., S. Papper, and M. M. Ashley. Variations in renal excretion of sodium independent of change in adrenocortical hormone dosage in patients with Addison's disease. J. clin. Endocr. 1955, 15, 1459.

3. Mueller, C. B., A. Surtshin, M. R. Carlin, and H. L. White. Glomerular and tubular influences on sodium and water excretion. Amer. J. Physiol. 1951, 165, 411.

4. Blake, W. D., R. Wégria, H. P. Ward, and C. W. Frank. Effect of renal arterial constriction on excretion of sodium and water. Amer. J. Physiol. 1950, 163, 422.

5. Bradley, S. E., and W. D. Blake. Pathogenesis of renal dysfunction during congestive heart failure. Amer. J. Med. 1949, 6, 470.

6. Surtshin, A., D. Rolf, and H. L. White. Constancy of sodium excretion in the presence of chronically altered glomerular filtration rate. Amer. J. Physiol. 1951, 65, 429.

7. Epstein, F. H. Renal excretion of sodium and the concept of a volume receptor. Yale J. Biol. Med. 1956, 29, 282.

8. Tobian, L., S. Perry, and J. Mork. The relationship of the juxtaglomerular apparatus to sodium retention in experimental nephrosis. Ann. intern. Med. 1962, 57, 382.

9. Selkurt, E. E. Effect of pulse pressure and mean arterial pressure modification on renal hemodynamics and electrolyte and water excretion. Circulation 1951, 4, 541.

10. Tobian, L. Relationship of juxtaglomerular apparatus to renin and angiotensin. Circulation 1962, 25, 189.

11. Merrill, A. J., J. L. Morrison, and E. S. Brannon. Concentration of renin in renal venous blood in patients with chronic heart failure. Amer. J. Med. 1946, 1, 468.

12. Hartroft, P. M. Juxtaglomerular cells. Circulat. Res. 1963, 12, 525.

13. Davis, J. O., P. M. Hartroft, E. O. Titus, C. C. J. Carpenter, C. R. Ayers, and H. E. Spiegel. The role of the renin-angiotensin system in the control of aldosterone secretion. J. clin. Invest. 1962, 41, 378.

14. Tobian, L., A. Tomboulian, and J. Janecek. The effect of high perfusion pressures on the granula- 
tion of juxtaglomerular cells in an isolated kidney. J. clin. Invest. 1959, 38, 605.

15. Vander, A. J., R. L. Malvin, W. S. Wilde, J. Lapides, L. P. Sullivan, and V. M. MacMurray. Effects of adrenalectomy and aldosterone on proximal and distal tubular sodium reabsorption. Proc. Soc. exp. Biol. (N. Y.) 1958, 99, 323.

16. Williamson, H. E., T. W. Skulan, and F. E. Shideman. Effects of adrenalectomy and desoxycorticosterone on stop-flow patterns of sodium and potassium in the rat. J. Pharmacol. exp. Ther. 1961, 131, 49.

17. Gottschalk, C. W., and M. Mylle. Micropuncture study of pressures in proximal and distal tubules and peritubular capillaries of the rat kidney during osmotic diuresis. Amer. J. Physiol. 1957, 189, 323.

18. Taylor, M. G., and E. Ullmann. Glomerular filtration after obstruction of the ureter. J. Physiol. (Lond.) 1961, 157, 38.

19. Rector, F. C. Personal communication.

20. Ganong, W. F., and P. J. Mulrow. The effect of aortic constriction on aldosterone secretion in hy- pophysectomized dogs. J. clin. Invest. 1962, 41, 1503.

21. Barbour, B. H., J. D. H. Slater, A. G. T. Casper, and F. C. Bartter. Role of the kidney in the control of aldosterone secretion by dietary sodium (abstract). Circulation 1962, 26, 683.

22. Biron, P., E. Koiw, W. Nowaczynski, J. Brouillet, and $\mathrm{J}$. Genest. The effects of intravenous infusions of valine-5 angiotensin II and other pressor agents on urinary electrolytes and corticosteroids, including aldosterone. J. clin. Invest. 1961, 40, 338.

23. Laragh, J. H., M. Angers, W. G. Kelly, and S. Lieberman. The effect of epinephrine, norepinephrine, angiotensin II, and others on the secretory rate of aldosterone in man. J. Amer. med. Ass. 1960, 174, 234.

24. Connor, T. B., W. C. Thomas, Jr., L. Haddock, and J. E. Howard. Unilateral renal disease as a cause of hypertension: its detection by ureteral catheterization studies. Ann. intern. Med. 1960. $52,544$. 